\title{
Antibiotic sensitivity of gonococci and treatment of gonorrhoea in Uganda
}

\author{
O. P. ARYA
}

Senior Medical Officer, Makerere University College Health Service; Hon. Sen. Lecturer, Dept. of Preventive Medicine, Makerere University College, Kampala, Uganda

\author{
AND IAN PHILLIPS * \\ Lecturer in Medical Microbiology, Makerere University College, Kampala, Uganda
}

VENEREAL disease, especially gonorrhoea, is of very common occurrence among students of Makerere University College, in Kampala, Uganda (Arya and Bennett; 1967, 1968), and this provides an excellent opportunity for the study of the treatment of gonorrhoea. Most patients are seen by one doctor, and almost all can be followed up until it is clear that they are either free from infection or have been re-infected. Furthermore they are prepared to be frank about reexposure, making it relatively easy to distinguish true failures of treatment from re-infection.

This study was aimed at determining the minimum useful dose of the various preparations of penicillin or tetracycline available to us for the treatment of acute gonococcal urethritis in males.

The minimum inhibitory concentration (M.I.C.) of penicillin was determined for all strains of gonococci isolated.

\section{Clinical investigations and treatment}

As many as possible of the men with urethritis attending the clinic during the period March to December, 1968, were referred to one doctor (O.P.A.) and included in the study. In each case, following a clinical examination, a smear of urethral pus was made and a sample was collected on a charcoal swab, and sent to the laboratory in Stuart's transport medium.

The patient was then randomly allocated to a treatment regime, of which there were twelve (Table I) in three main groups:

A. Long-acting penicillin.

B. Medium- and short-acting penicillins.

C. Tetracyclines.

Within the penicillin groups, doses ranged from 0.6 to 2.45 megaunits given on one occasion by intramuscular injection. Tetracycline was administered either by a combination of intramuscular and oral routes given on one occasion, or by courses of oral doses lasting 2 or 5 days.

Follow-up visits were arranged for 2 days, 4 days, 1 week, 2 weeks, 3 weeks, and 3 months. After questioning about re-exposure and a clinical examination, any discharge was sampled and examined bacteriologically. If a patient failed to attend the clinic within 2 weeks, he was visited and questioned in his room in the College.

$\star^{\star}$ Present Address : Dept. Clinical Microbiology, St. Thomas' Hospital, London, S.E.1.
T A B L E I Treatment regimes and total dosage

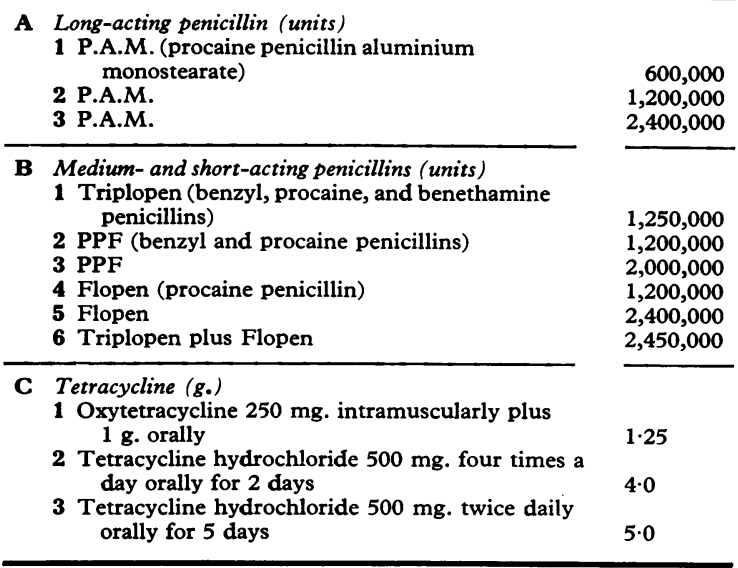

Persistent discharge at follow-up was classed either as failure or as re-infection on the basis of the history: reinfection was assumed if re-exposure was admitted. Failures were further classified as being due to persisting gonorrhoea or to concomitant non-gonococcal urethritis on the results of bacteriological investigations. The clinician was given these results as soon as possible by the laboratory, but was not told the antibiotic sensitivity of the gonococcus isolated.

Patients in whom the infection failed to respond to low doses of penicillin were treated with one of the high dosage penicillin regimes, and those who again failed to respond were given $5 \mathrm{~g}$. tetracycline over 5 days. Once any schedule of treatment had been shown to be ineffective, it was abandoned.

\section{Laboratory investigations}

Gram-stained films were examined for pus cells, Gramnegative intra- or extra-cellular diplococci, and other organisms, and the results were roughly quantitated. Pus from the Stuarts' swabs was plated and gonococci were identified as Gram-negative diplococci that grew on Thayer-Martin medium (Thayer and Martin, 1966), failed to grow on nutrient agar, and fermented glucose, but did not ferment maltose or sucrose.

A diagnosis of gonorrhoea was made if gonococci were grown or if typical Gram-negative intracellular diplococci were seen but did not grow. A diagnosis of resolving 
gonorrhoea was made when Gram-negative extracellular diplococci were seen but no gonococci were grown; such a finding after treatment was not considered as a failure. A diagnosis of non-gonococcal urethritis (NGU) was made if there were none of these findings. Patients shown to have only NGU on their first visit were excluded from the study.

Minimum inhibitory concentrations of antibiotics were determined on solid medium (Wilkinson, 1962), made up of blood agar base (Oxoid, CM271) plus heated human blood plus antibiotic. The inoculum of gonococci was made from a just-turbid suspension in nutrient broth, made from growth scraped from a chocolate agar plate. It was applied to the antibiotic-containing plates with a multiple inoculator. W.H.O. reference strains, supplied by Dr. Alice Reyn of the Statens Seruminstitut, Copenhagen, were used as standards.

After the end of the trial proper, a further 120 episodes of gonorrhoea were treated on a non-random basis, mostly with 2.4 megaunits procaine penicillin. These results are discussed separately.

\section{Results}

During the period of study 237 men attended the clinic with 381 attacks of urethritis, of which 328 were included in the study. One patient had six episodes during the 9 months, three had 5, five had 4, twelve had 3, and 35 had two episodes; the remaining 181 men had one episode only.

A diagnosis of gonorrhoea was made in 242 instances out of the 328: of these 216 were seen within 1 or 2 days of the onset of urethritis and only fourteen after more than one week. The source of infection was a prostitute in 192 cases, a continuing acquaintance in 128, the wife in four cases, and was unknown in four more. Previous treatment had been given in 28 of the 328 episodes, usually from a hospital (17) or a private doctor (9), but by self-medication in two cases.

Data on follow-up of the 242 episodes of gonorrhoea are given in Table II. Almost 70 per cent. of the patients were followed for more than 5 weeks: shorter follow-up was usually a consequence of reinfection-almost 30 per cent. were re-infected within one month.

\section{BACTERIOLOGICAL RESULTS}

Of the 242 cases of gonorrhoea, 186 had positive results to cultures. The M.I.C. of penicillin for 173 of these strains was determined: about 80 per cent. of them showed diminished sensitivity to penicillin (Table III). Such strains were almost always slightly less sensitive to tetracycline (Table IV) and were almost invariably resistant to streptomycin.
TABLE I I Penicillin sensitivity of gonococci

\begin{tabular}{|c|c|c|c|c|c|c|}
\hline \multirow{2}{*}{$\frac{\text { Gonococci }}{\substack{\text { Penicillin MIC } \\
(\mu \mathrm{g} . / \mathrm{ml} .)}}$} & \multicolumn{3}{|c|}{ Sensitive } & \multicolumn{3}{|c|}{ Less sensitive } \\
\hline & 0.015 & 0.03 & 0.06 & $0 \cdot 12$ & 0.24 & 0.48 \\
\hline Number of strains & 14 & 19 & 2 & 11 & 28 & 99 \\
\hline Percentage & 20 & & & 80 & & \\
\hline
\end{tabular}

T A B LE IV Tetracycline sensitivity of penicillinsensitive and resistant strains

\begin{tabular}{|c|c|c|c|c|}
\hline \multirow{2}{*}{$\begin{array}{l}\text { Minimum inhibitory concentration } \\
(\mu \mathrm{g} . / \mathrm{ml} .)\end{array}$} & \multicolumn{2}{|c|}{ Penicillin 0.06} & \multicolumn{2}{|c|}{ Penicillin 0.12} \\
\hline & 0.5 & 1.0 & 0.5 & 1.0 \\
\hline Number of strains & 16 & 0 & 2 & 31 \\
\hline Percentage & 100 & 0 & 6 & 94 \\
\hline
\end{tabular}

RESULTS OF TREATMENT

Of the 41 cases of failure, 39 were seen during the first week, and two during the second week after treatment.

Table $\mathrm{V}$ shows the results of treating 35 episodes of infection due to penicillin sensitive gonococci. There was only one failure; this occurred in a patient given 0.6 megaunits P.A.M.

The results of treatment of less sensitive gonococci are shown in Table VI: there were 170 treatments, including second and third treatments of failures, for which results were similar to those obtained when the same dose was given as a first treatment.

Table VII gives combined results for all treatments. It includes, in addition to the material in Tables V and VI, results for patients from whom gonococci were isolated but whose sensitivity was not determined; patients with microscopic evidence of gonorrhoea but negative cultures; and the series of 120 patients treated since the end of the trial proper.

\section{Discussion}

The present study has confirmed our previous finding of a very high incidence of diminished penicillin sensitivity among strains of Neisseria gonorrhoeae isolated in Uganda (Phillips, Fernandes, Pirani, and Wagaine; 1969). Although none of our strains had M.I.C.s of more than $0.48 \mu \mathrm{g}$. $/ \mathrm{ml}$. penicillin, the situation clearly resembles that found in South East Asia and the Western Pacific by Reyn (1969). In Uganda, diminished penicillin sensitivity is almost invariably linked with total resistance to strepto-

TAB IE I F Follow-up

\begin{tabular}{|c|c|c|c|c|c|c|}
\hline Follow-up period & 3 months & 9-11 weeks & 5-8 weeks & $2-4$ weeks & Less than 2 weeks & Total \\
\hline No. of episodes & 103 & 8 & 35 & 78 & 18 & 242 \\
\hline
\end{tabular}


T A BLE V Treatment of infection due to sensitive gonococci

\begin{tabular}{|c|c|c|c|c|c|}
\hline Treatment & $\begin{array}{l}\text { No. of } \\
\text { episodes }\end{array}$ & \multicolumn{4}{|l|}{ Result } \\
\hline Total episodes & 35 & 1 & $4^{\star}$ & 1 & 97 \\
\hline
\end{tabular}

*Gram-negative extracellular diplococci seen but no gonococci grown in two cases.

T A B L E V I Treatment of infection due to less-sensitive gonococci

\begin{tabular}{|c|c|c|c|c|c|}
\hline Treatment & $\begin{array}{l}\text { No. of } \\
\text { episodes }\end{array}$ & \multicolumn{4}{|l|}{ Results } \\
\hline $\begin{array}{ll}\text { C } & \text { Tetracyclines (g.) } \\
1 & 1 \cdot 25 \\
2,3 & 4-5\end{array}$ & $\begin{array}{l}17 \\
17\end{array}$ & $\begin{array}{l}9 \\
1\end{array}$ & $\begin{array}{l}1 \\
0\end{array}$ & $\begin{array}{l}2 \\
0\end{array}$ & $\begin{array}{l}40 \\
94\end{array}$ \\
\hline
\end{tabular}

T A B L E VII Results of treatment of 432 episodes of gonorrhoea

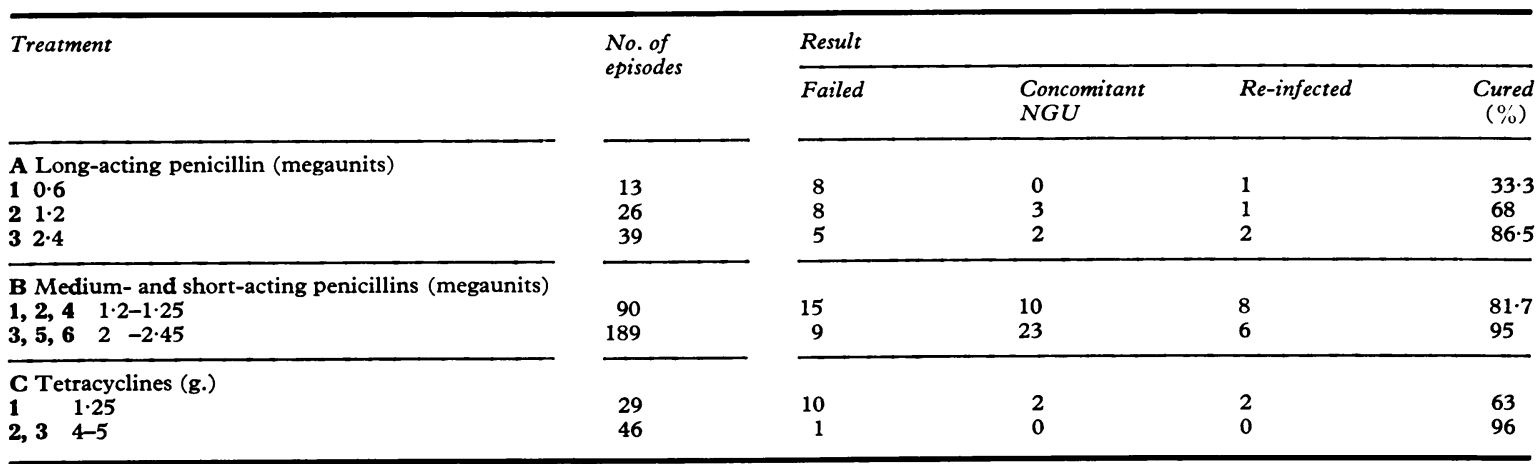

mycin, and usually also with slightly diminished sensitivity to tetracycline. Links of this kind have been discussed by Reyn (1961) but the clinical significance of minor degrees of resistance is not always clear.

In the interpretation of the results of treating gonorrhoea it is important to define failure. We based its diagnosis on a finding of Gram-negative intracellular diplococci in direct films, or culture of gonococci, from discharge persisting or reappearing after treatment, in a man who denied re-exposure. All failures, on these criteria, were seen within 2 weeks, and the majority within one week. We thus agree with Willcox (1967) and with Csonka and Knight (1967) that 2 weeks is long enough for the detection of failures of treatment. It is notable also that sensitivity testing did not reveal any discrepancies. However, fifteen men who returned within the first 2 weeks complaining of recurrent urethritis were not classed as failures because they admitted to repeated intercourse, which carries a very high risk of infection in this environment.

The interpretation of bacteriological results was clear except in cases examined after treatment with low doses of penicillin in which Gram-negative extracellular diplococci were seen in smears but no 
Neisseria were grown. Because the discharge almost always disappeared without further treatment, the organisms were assumed to be dead gonococci and the treatment result was not classed as a failure. As there were only five such cases, results would have been little affected had the opposite classification been made (Curtis and Wilkinson, 1958).

Our results indicated that it was possible to cure gonorrhoea due to sensitive organisms with any of the schedules that we investigated. When all cases are considered there was a clear improvement in results with increased dosage in each category. Thus $2 \cdot 4$ megaunits P.A.M. gave better results than 0.6 or 1.2 megaunits, $2-2 \cdot 45$ megaunits of medium- and short-acting penicillin gave better results than 1.21.25 megaunits, and 4-5 g. tetracycline were better than $1.25 \mathrm{~g}$. oxytetracycline. Furthermore, it seems that medium- and short-acting pencillins gave better results than long-acting penicillins- 83 per cent. cured against 64 per cent. with low dosages, and 95 per cent. against 82 per cent. with higher dosages. Mixtures of penicillins appeared to have no advantage over procaine penicillin. Our findings with low doses of tetracycline were disappointing in view of the results of Shapiro and Lentz (1965) who had a 94 per cent. success rate in treating women with gonorrhoea with the dosage of oxytetracycline that we used, and of McLone, Kiley, and Hackney (1967), who cured between 83.7 and 93.8 per cent. of men with a single oral dose of $1.5 \mathrm{~g}$. oxytetracycline. As we were able to treat only a few infections due to sensitive organisms in this series, we can only suspect that our failures were due to diminished tetracycline sensitivity.

Taking all this into account, together with considerations of cost and convenience of administration, we conclude that procaine penicillin in a single dose of 2.4 megaunits is the treatment of choice in Uganda, with a course of $4 \mathrm{~g}$. of tetracycline second choice, to be used when penicillin fails or cannot be given.

\section{Summary}

A study of gonorrhoea in a group of male university students in Uganda is described. In most cases it was possible to obtain an honest history, to observe the patients for long periods, and to distinguish failures of treatment from re-infection with some assurance.

80 per cent. of strains of gonococci isolated from this group showed a diminished sensitivity to penicillin, almost always associated with diminished tetracycline sensitivity and total resistance to streptomycin.

Infections with sensitive strains responded well to treatment with $0 \cdot 6-2.45$ megaunits penicillin, or with 1.25-5 g. tetracycline. In the group infected with less sensitive strains, a long-acting penicillin was less effective than medium- or short-acting pre- parations, a dose of up to 1.25 megaunits often failed to cure, while doses of 2-2.45 megaunits penicillin and 4-5 g. tetracycline both cured 94 per cent. of patients. Results for all patients were very similar to those for patients with less sensitive organisms because of the large preponderance of this latter group.

We thank Mr. R. Fernandes for his careful technical assistance. We also thank Prof. R. Blowers and $\mathrm{Mr}$. Stephen Lwanga for helpful discussion of our results. Pfizer Ltd., Kampala, supplied the oxytetracycline.

\section{References}

ARYa, O. P., and BennetT, F. J. (1967). Brit. F. vener. Dis., 43, 275.

CsonkA, G. W., and KNIGHT, G. J. (1967). Ibid., 43, 161. CURTIS, F. R., and WILKINSON, A. E. (1958). Ibid., 34, 70. McLone, D. G., Kiley, D. J., and HaCkNeY, J. F. (1967). Ibid., 43, 166.

Phillips, I., Fernandes, R., Pirani, A. A., and Wagaine, D. (1969). East Afr. med. F., 46, 38.

REYN, A. (1961). Brit. F. vener. Dis., 37, 145.

- (1969). Bull. Wld Hlth Org., 40, 257.

Shapiro, L. H., and LeNTZ, J. W. (1965). Amer. F. Obstet. Gynec., 94, 536.

Thayer, J. D., and Martin, J. E. (1966). Publ. Hith Rep. (Wash.), 81, 559.

WILkINSON, A. E. (1962). Brit. F. vener. Dis., 38, 145.

WILlcox, R. R. (1967). Ibid., 43, 157.

Sensibilité des gonocoques aux antibiotiques et traitement de la gonococcie en Ouganda

\section{SOMMAIRE}

On fait état d'une étude de la gonococcie dans un groupe d'étudiants mâles de l'Université, en Ouganda. Dans la plupart des cas, il a été possible d'obtenir un historique sincère, d'observer longtemps les malades et de distinguer avec quelque certitude les échecs du traitement des réinfections.

80 pour cent des souches de gonocoques isolées dans ce groupe montrèrent une sensibilité diminuée à la penicilline, presque toujours associée à une sensibilité diminuée à la tétracycline et à une résistance totale à la streptomycine.

Les infections dues à des souches sensibles répondirent bien à un traitement avec $0,6-2,45$ méga-unités de pénicilline ou à $1,25-5 \mathrm{~g}$ de tétracycline. Dans le groupe des sujets infectés avec des souches moins sensibles, la pénicilline longue-action fut moins efficace que les préparations d'action moyennement prolongée ou d'action courte; une dose allant jusqu'à 1,25 méga-unités échoua souvent, alors que les doses de 2-2,45 méga-unités de pénicilline et de $4-5 \mathrm{~g}$ de tétracycline guérissaient, dans les deux cas, 94 pour cent des malades. Les résultats, pour l'ensemble de ces malades, furent très voisins de ceux du groupe à germes moins sensibles du fait de la large prépondérence de ce dernier. 